\title{
MENINGKATKAN KOMPETENSI GURU MATA PELAJARAN DALAM MENYUSUN RENCANA PELAKSANAAN PEMBELAJARAN (RPP) MELALUI SUPERVISI AKADEMIK DI SMP NEGERI 19 KABUPATEN TEBO
}

\author{
USMANIAR \\ SMP Negeri 19 Kabupaten Tebo Provinsi Jambi \\ usmaniar1969@gmail.com
}

\begin{abstract}
ABSTRAK
Tujuan penelitian ini untuk mendeskripsikan dan mendapatkan informasi tentang upaya meningkatkan Kompetensi Guru dalam menyusun RPP melalui Supervisi akademik di SMP Negeri 19 Kabupaten Tebo Provinsi Jambi. Penelitian ini merupakan Penelitian Tindakan Sekolah (PTS). Penelitian ini dilakukan pada semester ganjil tahun ajaran 2019/2020. Prosedur penelitian dalam penelitian ini meliputi perencanaan, tindakan, obeservasi dan refleksi. Penelitian ini terdiri dari 2 (dua) siklus dengan 4 (empat) kali pertemuan. Subjek penelitian terdiri dari 18 orang guru mata pelajaran di SMP Negeri 19 Kabupaten Tebo. Data penelitian dikumpulkan dengan menggunakan instrument penilaian. Berdasarkan hasil penelitian dapat disimpulkan bahwa melalui supervisi akademik dapat meningkatkan Kompetensi Guru mata pelajaran dalam menyusun Rencana Pelaksanaan Pembelajaran (RPP) di SMP Negeri 19 Kabupaten Tebo. Hal ini dilihat dari kesiapan guru dalam pelaksanaan pembelajaran. Disamping itu berdasarkan hasil penilitian yang dilakukan nilai rata-rata RPP yang dibuat oleh guru mata pelajaran juga mengalamin peningkatan yaitu pada siklus 1 rata- rata nilai 71,2 dan pada siklus 2 dengan nilai rata-rata 82,5.
\end{abstract}

Kata Kunci: kompetensi guru mata pelajaran, rencana pelaksanaan pembelajaran, supervisi akademik

\section{PENDAHULUAN}

Pendidikan adalah upaya yang secara sadar dirancang untuk membantu seseorang atau sekelompok orang dalam mengembangkan ilmu pengetahuan, pandangan hidup, sikap hidup, dan keterampilan hidup baik yang bersifat manual individual maupun sosial (Sagala, 2006: 1).

Perubahan yang begitu dinamis pada dunia pendidikan mendorong kepala sekolah memiliki kompetensi manajerial yang handal dan mumpuni. Kompetensi tersebut menjadi bekal kepala sekolah dalam menjalankan tugas dan fungsinya secara baik dan optimal. Permendikbud Nomor 6 Tahun 2018 tentang Penugasan Guru Sebagai Kepala Sekolah. Beban kerja Kepala Sekolah sepenuhnya untuk melaksanakan tugas pokok manajerial, pengembangan kewirausahaan, dan supervisi kepada guru dan tenaga kependidikan. Tujuannya agar kepala sekolah dapat fokus pada pengembangan 8 standar pendidikan. Disisi lain apabila kekurangan guru, kepala sekolah dapat melaksanakan peran guru pada tugas pembelajaran.

Kepala sekolah mempunyai tugas untuk melaksanakan supervisi akademik. Implementasinya dengan membina guru untuk meningkatkan mutu proses pembelajaran. Sasaran supervisi akademik adalah guru dalam meningkatkan kompetensi pelaksanaan proses pembelajaran, penyusunan silabus dan RPP, pemilihan strategi/metode/teknik pembelajaran, penggunaan media dan teknologi informasi dalam pembelajaran, menilai proses dan hasil pembelajaran serta penelitian tindakan kelas (Modul Supervisi Akademik, Dirjen PMPTK, 2010). Berdasarkan penjelasan umumnya, kompetensi adalah seperangkat pengetahuan, keterampilan dan perilaku yang harus dimiliki, dihayati, dan dikuasai oleh suatu profesi dalam melaksanakan tugas keprofesionalannya (Undang-Undang Republik Indonesia Nomor 14 Tahun 2005 tentang Guru dan Dosen, pasal 1 butir 10). Sagala et, al mengemukakan sepuluh kompetensi dasar yang harus dimiliki guru, yaitu: (1) menguasai landasan-landasan pendidikan; (2) menguasai bahan pelajaran; (3) kompetensi mengelola program belajar mengajar; (4) kompetensi mengelola kelas; (5) kompetensi mengelola interaksi belajar mengajar; (6) menilai hasil belajar siswa; (7) kompetensi mengenal dan menterjemahkan kurikulum; (8) mengenal 
fungsi dan program bimbingan dan penyuluhan; (9) memahami prinsip-prinsipdan hasil pengajaran; (10) mengenal dan menyelenggarakan administrasi pendidikan (Sagala, 2006 : 210). Adapun Pedagogi dapat didefinisikan sebagai, seni atau strategi mengajar. Jadi kompetensi pedagogik adalah kompetensi mengelola pembelajaran peserta didik yang meliputi pemahaman terhadap peserta didik, perancangan dan pelaksanaan pembelajaran, evaluasi proses dan hasil belajar, dan pengembangan peserta didik untuk mengaktualisasikan berbagai potensi yang dimilikinya (Gunawan, Asrifan, 2019).

Dalam meningkatkan kualitas sumberdaya manusia, guru mempunyai peran yang sangat penting karena kualitas guru merupakan salah satu variabel yang terpenting dalam menentukan kualitas pendidikan, khususnya yang berkaitan dengan kompetensi guru mata pelajaran dalam membuat perangkat pembelajaran. (Ali, 2019). Mencermati salah satu kompetensi guru mata pelajaran dalam proses pembelajaran, yaitu sebagai perencana pembelajaran, setiap guru pada satuan pendidikan berkewajiban menyusun RPP yang lengkap dan sistematis agar pembelajaran efektif dan bermutu. Pembelajaran yang berlangsung secara efektif dan bermutu akan berimplikasi pada peningkatan mutu proses dan hasil belajar peserta didik. Rendahnya kompetensi guru dalam menyusun Rencana Pelaksanaan Pembelajaran (RPP) ini disebabkan berbagai macam faktor.

Dari hasil wawancara dan tanya jawab kepada guru, hal tersebut disebabkan karena terlalu banyak syarat administrasi sehingga untuk mencari jalan yang praktis, sementara informasi yang diterima lewat pendidikan dan pelatihan belum tuntas secara mendalam sehingga pemahaman materi masih mengambang, kesibukan pribadi di luar kedinasan tidak bisa di tinggalkan sehingga tidak ada kesempatan untuk mempelajari sendiri di rumah. Atas dasar itulah, guru harus terus meningkatkan kompetensi terutama bagi guru mata pelajaran. Peningkatan kompetensi tersebut akan menghasilkan guru yang professional sehingga terwujudlah proses pendidikan yang bermutu baik di level kelas maupun sekolah secara keseluruhan. Kelemahan guru mata pelajaran dalam menyusun RPP yang baik dan benar akan bisa teratasi dengan adanya kegiatan peningkatan kompetensi yang diselenggarakan oleh kepala sekolah dalam wujud supervise akademik secara berkesinambungan. Dengan memaksimalkan kegiatan tersebut dihajatkan dapat mengurai kesulitan guru sekaligus memberikan peluang bagi guru untuk meningkatkan kompetensi dan keterampilan guru dalam proses kegiatan belajar mengajar.

Rencana Pelaksanaan Pembelajaran (RPP) adalah instrumen perencanaan yang lebih spesifik dari silabus. Rencana Pelaksanaan Pembelajaran ini dibuat untuk memandu guru dalam mengajar agar tidak melebar jauh dari tujuan pembelajaran. Dalam pengertian yang lain, Suriati (2018: 274) mengemukakan bahwa RPP adalah rencana yang menggambarkan prosedur dan pengorganisasian pembelajaran untuk mencapai satu kompetensi dasar yang ditetapkan dalam standar isi dan dijabarkan dalam silabus secara lengkap dan sistematis sehingga proses pembelajaran menjadi efektif.

Adanya kegiatan pengembangan kompetensi bagi guru mata pelajaran dalam menyusun RPP secara berkelanjutan menjadi bagian dari supervisi akademik yang bisa dilakukan oleh kepala sekolah. Supervisi akademik merupakan kegiatan terencana yang ditujukan pada aspek kualitatif sekolah dengan membantu guru melalui dukungan dan evaluasi pada proses belajar dan pembelajaran yang dapat meningkatkan hasil belajar. Tujuan supervisi adalah memberikan layanan dan bantuan untuk meningkatkan kualitas mengajar guru di kelas yang pada intinya bertujuan untuk meningkatkan kualitas belajar siswa. Bukan saja memperbaiki kompetensi mengajar tetapi juga mengembangkan potensi kualitas guru (Sahertian, 2000:19). Pada penjelasan yang lain, Menurut Sahertian dalam Astuti, (2016: 117) dijelaskan bahwa supervisi adalah usaha memberi layanan kepada guru-guru baik secara individual maupun secara kelompok dalam usaha memperbaiki pengajaran. Sedangkan Purwanto (2013: 35) menjelaskan bahwa supervisi merupakan akivitas pembinaan yang direncanakan untuk membantu guru dan pegawai sekolah dalam melakukan pekerjaan secara efektif. 
Upaya memperbaiki dan meningkatkan mutu pendidikan seakan tidak pernah berhenti. Reformasi pendidikan tidak cukup hanya dengan perubahan dalam sektor kurikulum, baik struktur maupun prosedur penulisannya. Pembaharuan kurikulum akan lebih bermakna bila diikuti oleh perubahan praktik pembelajaran di dalam maupun di luar kelas. Keberhasilan implementasi kurikulum sangat dipengaruhi oleh kompetensi guru yang akan menerapkan dan mengaktualisasikan kurikulum tersebut. Tidak jarang kegagalan implementasi kurikulum disebabkan oleh kurangnya pengetahuan, keterampilan dan kompetensi guru dalam memahami tugas tugas yang harus dilaksanakannya. Hal itu berarti bahwa guru sebagai pelaksana kegiatan pembelajaran menjadi kunci atas keterlaksanaan kurikulum di sekolah. Mulyasa (2011: 37) menyatakan bahwa, "Tugas guru untuk menjadi guru profesional meliputi, mendidik, mengajar, dan melatih“. Mendidik berarti meneruskan dan mengembangkan nilai nilai hidup. Mengajar berarti meneruskan dan mengembangkan ilmu pengetahuan dan teknologi. Sedangkan melatih berarti mengembangkan keterampilan keterampilan pada siswa.

Mencermati uraian di atas, terlihat betapa besarnya peran guru dalam membantu pertumbuhan dan perkembangan peserta didik. Guru memiliki peran dan fungsi yang sangat penting dalam membentuk kepribadian, akhlak, mentalitas, dan moral anak. Dengan demikian dapat dikatakan tercapainya tujuan pendidikan di sekolah sangat dipengaruhi oleh sikap guru dalam melaksanakan tugas profesinya. Dalam kurikulum 2013, guru tidak perlu membuat sendiri silabus karena sudah dipersiapkan dari pemerintah, namun sebagai seorang guru tisak lepas dari fungsi administrasi.

Dalam kaitannnya dengan fungsi administrasi ini, lebih spesifik dalam hal proses belajar mengajar, Gagne dan Berliner dalam Makmun (2005: 23) mengemukakan tiga fungsi atau peran guru dalam proses tersebut, yaitu sebagai : 1) Perencana (planner) yang harus mempersiapkan apa yang harus dilakukan di dalam proses belajar mengajar (pre-teaching problems). 2) Pelaksanaan (organizer) yang harus menciptakan situasi, memimpin, merangsang, menggerakkan, dan mengarahkan kegiatan belajar mengajar sesuai dengan rencana, bertindak sebagai nara sumber (source person), konsultan kepemimpinan (leader), yang bijaksana dalam arti demokratis dan humanistik (manusiawi) selama proses berlangsung (during teaching problems). 3) Penilai (evaluator) yang harus mengumpulkan, menganalisis, menafsirkan dan akhirnya harus memberikan pertimbangan (judgement) atas tingkat keberhasilan belajar mengajar tersebut berdasarkan kriteria yang ditetapkan baik mengenai aspek keefektifan prosesnya, maupun kualifikasi produk (output)-nya. Sementara itu secara adminstrasi kepala sekolah mempunyai tugas sebagai supervisor yang tugasnya membimbing kesulitan guru.

Menyoroti salah satu peran guru dalam proses pembelajaran, yaitu sebagai perencana pembelajaran, setiap guru pada satuan pendidikan berkewajiban menyusun RPP yang lengkap dan sistematis agar pembelajaran efektif dan bermutu. Pembelajaran yang berlangsung secara efektif dan bermutu akan berimplikasi pada peningkatan mutu proses dan hasil belajar peserta didik. Perencanaan pembelajaran merupakan langkah yang sangat penting sebelum pelaksanaan pembelajaran. Perencanaan yang matang diperlukan supaya pelaksanaan pembelajaran berjalan secara efektif. Perencanaan pembelajaran dituangkan ke dalam Rencana Pelaksanaan Pembelajaran (RPP). RPP memuat Kompetensi Inti (KI) kompetensi Dasar (KD), indikator yang akan dicapai, materi yang akan dipelajari, metode pembelajaran, langkah pembelajaran, media pembelajaran, dan sumber belajar serta penilaian. Guru pada satuan pendidikan berkewajiban menyusun RPP secara lengkap dan sistematis agar pembelajaran berlangsung secara interaktif, inspiratif, menyenangkan. Karena RPP menjadi pedoman bagi guru khususnya guru mata pelajaran dalam menyelanggarakan kegiatan pembelajaran. Di dalam RPP harus tercermin dengan jelas gambaran kegiatan pembelajaran yang mampu menumbuhkan pembelajaran yang menantang dan memotivasi peserta didik untuk berpartisipasi aktif (Zain, 2019: 469).

Upaya perwujudan pengembangan silabus menjadi perencanaan pembelajaran yang implementatif memerlukan kompetensi yang komprehensif. Kompetensi itulah yang dapat mengantarkan guru menjadi tenaga yang professional. Guru yang professional harus 
memiliki 5 (lima) kompetensi yang salah satunya adalah kompetensi penyusunan rencana pembelajaran. Namun dalam kenyataannya masih banyak guru yang belum mampu menyusun rencana, sebagian guru tidak membuat sendiri silabus dan RPP mata pelajaran yang diampu sehingga hal ini secara otomatis berimbas pada kualitas pembelajaran. Permasalahan yang peneliti temui di atas, sejalan dengan permasalahan yang diungkap oleh Mulyasa dalam Yurnalis, (2018: 505) yang menyatakan ada tujuh kesalahan yang sering dilakukan oleh guru khususnya dalam proses belajar-mengajar yaitu: 1) Mengambil jalan pintas dalam pembelajaran (tidak membuat persiapan tertulis dalam mengajar dalam artian tidak membuat perangkat pembelajaran seperti silabus, RPP, media, dan evaluasi); 2) Menunggu siswa berperilaku negatif (guru tidak memberikan perhatian dan penghargaan yang pantas kepada siswa yang berperilaku baik, sehingga siswa memiliki kesimpulan kalau ingin mendapat perhatian dari guru harus berperilaku yang negatif); 3) Menggunakan destructif disiplin (guru menggunakan disiplin yang dapat merusak perkembangan siswa); 4) Mengabaikan perbedaan siswa; 5) Merasa paling pandai; 6) Tidak adil (diskriminatif); 7) Memaksa hak siswa.

Berdasarkan hal-hal tersebut peneliti mengadakan sebuah penelitian tindakan sekolah dengan judul "Peningkatan Kompetensi Guru Dalam Menyusun Rencana Pelaksanaan Pembelajaran Melalui Supervisi Akademik SMP Negeri 19 Kabupaten Tebo Provinsi Jambi”.

\section{METODE PENELITIAN}

Penelitian yang dilakukan ini adalah penelitian tindakan. Menurut Zuriah, (2003:54) penelitian tindakan menekankan kepada kegiatan (tindakan) dengan mengujicobakan suatu ide ke dalam praktek atau situasi nyata dalam skala mikro yang diharapkan kegiatan tersebut mampu memperbaiki, meningkatkan kualitas dan melakukan perbaikan sosial. Penelitian tindakan yang dilakukan adalah penelitian tindakan sekolah (PTS).

Penelitian tindakan sekolah ini dilakukan di SMP Negeri 19 Kabupaten Tebo Provinsi Jambi, dilakukan dalam dua siklus, masing-masing siklus terdiri atas empat tahapan dalam tiap siklusnya. Diantaranya: 1) perencanaan, 2) tindakan, 3) observer, dan 4) refleksi. Model penelitian tindakan yang digunakan adalah model Stephen Kemmis dan Mc. Taggart. Mengadopsi dari Setyawan $(2008$; 49) model ini menggunakan sistem spiral yang dimulai dari rencana, tindakan, pengamatan, refleksi dan perencanaan kembali yang merupakan dasar untuk suatu ancangancang pemecahan masalah. Peneliti menggunakan model ini karena dianggap paling praktis dan aktual. Menurut Arikunto (2010: 203) "Instrumen penelitian adalah alat atau fasilitas yang digunakan oleh peneliti dalam mengumpulkan data agar pekerjaannya lebih mudah dan hasilnya lebih baik, dalam arti lebih cermat, lengkap, dan sistematis sehingga lebih mudah diolah".

Untuk mengetahui keefektifan suatu metode dalam kegiatan pembelajaran perlu diadakan analisa data. Pada penelitian ini menggunakan teknik analisis deskriptif kualitatif, yaitu suatu metode penelitian yang bersifat menggambarkan kenyataan atau fakta sesuai dengan data yang diperoleh. Untuk melihat kompetensi guru dari suatu pertemuan ke pertemuan selanjutnya, dan dari siklus I ke siklus II digunakan persentase. Adapun kriteria penilaian sebagai seperti dalam Tabel 1 berikut:

Tabel 1. Kriteria Penilaian RPP Yang Dibuat Guru Mata Pelajaran

\begin{tabular}{ccc}
\hline ANGKA & HURUF & KRITERIA \\
\hline $86-100$ & A & Sangat Baik \\
\hline $71-85$ & B & Baik \\
\hline $56-70$ & C & Cukup \\
\hline$<55$ & D & Kurang
\end{tabular}

Jika dalam perhitungan secara klasikal yang mendapatkan nilai 71 ke atas (minimal baik) kurang dari $85 \%$, maka dilanjutkan ke siklus kedua. 


\section{HASIL DAN PEMBAHASAN}

\section{Siklus 1}

Hasil penelitian tindakan yang dilakukan kepada 18 orang guru mata pelajaran di SMP Negeri 19 Kabupaten Tebo Provinsi Jambi pada semester ganjil pada tahun pelajaran 2019/2020. Penelitian ini dilaksanakan dalam dua siklus. Hasil dari penelitian pada siklus 1 akan menjadi tolak ukur perubahan dan perbaikan yang sesuai terhadap proses dan teknik yang akan diterapkan pada siklus II.

Berikut ini adalah hasil deskripsi dari guru yang telah membuat RPP sesuai dengan standar penulisan RPP.

Tabel 2. Perolehan Nilai Penyususnan RPP Siklus 1

\begin{tabular}{ccccc}
\hline No & Nilai & Kriteria & Jumlah & Persentase(\%) \\
& & & & 11 \\
\hline 1 & $86-100$ & A & 2 & 44,5 \\
\hline 2 & $71-85$ & B & 8 & 44,5 \\
\hline 3 & $56-70$ & C & 8 & - \\
\hline 4 & $<55$ & D & - & 100 \\
\hline & Jumlah & & 18 & \\
\hline
\end{tabular}

Dari Tabel 2 di atas dapat dijelaskan bahwa dari 18 guru yang mendapatkan nilai baik dalam penyusunan RPP berjumlah 10 orang atau 55,5\% dan nilai rata-ratanya 71,2. Dari hasil penilaian siklus 1 ini, karena secara klasikal lebih rendah $85 \%$ (dari kriteria yang ditetapkan), maka perlu perbaikan pada siklus 2 .

Masih rendahnya perolehan nilai dari RPP yang di buat guru dikarenakan RPP yang disusun guru belum lengkap, guru belum seluruhnya memahami dalam pemilihan metode dan model pembelajaran yang dituliskan dalam RPP yang disusun, guru belum menuliskan penilaian yang dilakukan, guru belum membuat kunci jawaban penilaian berikut rubriknya. Untuk memperbaiki kelemahan tersebut melalui supervisi akademik yang dilakukan kepala sekolah membimbing guru untuk memperbaiki kembali RPP yang disusun.

\section{Siklus II}

Berdasarkan hasil dari siklus satu bahwa masih banyak RPP yang dibuat guru mata pelajaran belum sesuai dengan standar penulisan untuk itu peneliti (kepala sekolah) melalui supervisi akademik mengarahkan, membimbing dan memberi contoh guru agar RPP yang disusun diperbaiki sesuai dengan ketentuan.

Berdasarkan hasil penilaian pada siklus II terjadi peningkatan pada kualitas RPP guru dimana dapat dilihat pada tabel 3 dibawah ini:

Tabel 3. Perolehan Nilai Penyususnan RPP Siklus 2

\begin{tabular}{lcccc}
\hline No & Nilai & Kriteria & Jumlah & Persentase(\%) \\
& $86-100$ & A & 5 & 28 \\
\hline 1 & $86-85$ & B & 11 & 61 \\
\hline 2 & $71-85$ & C & 2 & 11 \\
\hline 3 & $56-70$ & D & - & - \\
\hline 4 & $<55$ & & 18 & 100 \\
\hline & Jumlah & & &
\end{tabular}

Berdasarkan tabel 3 di atas 16 dari 18 orang guru atau $89 \%$ sudah menyusun RPP dengan baik, dan rata-rata perolehan nilainya 82,5.

\section{Pemabahasan}

Dari hasil perolehan nilai penyusunan RPP yang dilakukan guru pada siklus 1 dan Siklus II terdapat peningakatan seperti tergambar dalam table 4 berikut:

Tabel 4. Peningkatan Perolehan Nilai Penyusunan RPP

\begin{tabular}{cccc}
\hline No & Nilai & Siklus 1 & Siklus 2 \\
\hline 1 & A & 2 & 5 \\
\hline 2 & B & 8 & 11 \\
\hline 3 & C & 8 & 2 \\
\hline
\end{tabular}




\begin{tabular}{cccc}
\hline 4 & D & - & - \\
\hline & Rata-rata & 71,2 & 82,5
\end{tabular}

Dari tabel 4 di atas dapat dijelaskan bahwa pada siklus 1 yang telah menyusun RPP dengan baik sebanyak 10 dari 18 orang guru atau 55,5\% dan pada siklus II sebanyak 16 dari 18 orang guru atau $89 \%$. Terdapat peningkatan 33,5\%. Ditinjau dari perolehan nilai rata-rata pada siklus 1 dengan nilai 71,2 dan pada siklus II dengan nilai 82,5 atau terdapat peningkatan 11,30. Berdasarkan kriteria ketuntasan atau kesuksesan penelitian tindakan yang dilaksanakan, maka kegiatan ini dinyatakan berhasil atau dengan supervisi akademik yang dilakukan kepala sekolah dapat meningkatkan kompetensi guru dalam menyusun RPP.

\section{KESIMPULAN}

Berdasarkan hasil penelitian dan pembahasan yang telah dikemukakan, disimpulkan bahwa supervisi akademik yang dilakukan kepala sekolah dapat meningkatkan Kompetensi Guru dalam menyusun Rencana Pelaksanaan Pembelajaran di SMP Negeri 19 Kabupaten Tebo Provinsi Jambi. Hal ini dilihat dari kesiapan guru mata pelajaran dalam pelaksanaan pembelajaran. Disamping itu berdasarkan hasil penilitian yang dilakukan nilai rata-rata RPP yang dibuat oleh guru juga mengalami peningkatan yaitu pada siklus satu rata-rata nilai 71,2 dan pada siklus dua 82,5 .

\section{DAFTAR PUSTAKA}

Ali, R. H. (2019). Peningkatan Kompetensi Guru dalam Menyusun Rencana Pelaksanaan Pembelajaran (RPP) Melalui Supervisi Akademik oleh Kepala Sekolah di SD Negeri 43 Kota Ternate Tahun Pelajaran 2017-2018. Jurnal Geocivic, 2(2).

Arikunto, S. (2010). Prosedur penelitian: Suatu Pendekatan Praktik. (Edisi Revisi). Jakarta : Rineka Cipta.

Astuti, S. (2016). Penerapan Supervisi Akademik Untuk Meningkatkan Kompetensi Guru dalam Menyusun Administrasi Penilaian di SD Laboratorium UKSW, Jurnal Scholaria, 6 (1), 117 - 126.

Gunawan, G., \& Asrifan, A. (2019). Penerapan Kerja Kelompok Kegiatan MGMP Guru Ekonomi dalam Menyusun RPP untuk Meningkatkan Kompetensi Pedagogik. Celebes Education Review, 2(1), 31-36.

Purwanto, N. (2013). Evaluasi Hasil Belajar. Yogyakarta: Pustaka Pelajar.

Sagala, H. Syaiful. (2006). Administrasi Pendidikan Kontemporer. Bandung: Alfabeta.

Sahertian, Piet A. (2000). Konsep-Konsep dan Teknik Supervisi Pendidikan Dalam Rangka Pengembangan Sumber Daya Manusia. Jakarta: Rineka Cipta.

SetyawanPujiono. (2008). Desain PenelitianTindakan Kelas dan Teknik Pengembangann Kajian Pustaka. Yogyakarta: Universitas Negeri Yogyakarta.

Suriati. (2018). Menngkatkan Kompetensi Guru SDN 007 Kambung Baru Kecamatan Cerenti Dalam Menyusun Perencanaan Pembelajaran Melalui Supervisi Akademik. Jurnal PAJAR (Pendidikan dan Pengajaran), 2 (2), 274.

Yurnalis. (2018). Upaya Meningkatkan Kompetensi Guru Dalam Menyusun Perangkat Pembelajaran Melalui Supervisi Klinis di Sekolah Binaan Kecamatan Cerenti. Jurnal PAJAR (Pendidikan dan Pengajaran), 2(4), 505-515.

Zain, S. B. (2019). Upaya Meningkatkan Kompetensi Guru Dalam Menyusun Rencana Pelaksanaan Pembelajaran (Rpp) Melalui Supervisi Akademik Berkelanjutan Di Smk Negeri Dungaliyo Dan Smk Swasta Almamater Telaga. Indonesian Journal of Basic Education, 2(3), 469-480. 